\title{
PENTINGNYA PENGETAHUAN USIA DEWASA MENURUT HUKUM BAGI MAHASISWA DI PERGURUAN TINGGI
}

\author{
Delila Kania $^{1}$, Deni Zein Tarsidi ${ }^{2}$ \\ ${ }^{1,2}$ Fakultas Keguruan \& Ilmu Pendidikan, Universitas Pasundan Bandung \\ delila@unpas.ac.id ${ }^{1}$, denizein@ unpas.ac.id ${ }^{2}$
}

\begin{abstract}
This study aims to reveal how the understanding of adult age according to applicable law in Indonesia is for students of the Pancasila and Citizenship Education Study Program (PPKn) semester 1 (one) for the 2021-2022 academic year. The students in the subject of this research are aspiring teachers. Citizenship Education has the goal of making good citizens. The research method used is a case study approach to determine the extent of knowledge and understanding of legal adulthood in these students. Observations and interviews with semester 1 (one) students are to ensure the results of case study research. The implications of this legal age of adult knowledge will have an impact on understanding their rights and obligations as citizens. Students as legal subjects should know and understand the age of adulthood according to applicable law in Indonesia. This knowledge is very useful for students to protect their rights and interests in the life of the nation and state.
\end{abstract}

Keywords: Adult Age, Legal Knowledge, PPKn Students

\section{PENDAHULUAN}

Para mahasiswa baru yang terdapat di suatu perguruan tinggi, hasil observasi awal menunjukkan bahwa mereka ratarata berusia antara 18(delapan belas) sampai 19 (sembilan belas) tahun atau lebih. Umumnya mereka telah memiliki Kartu Tanda Penduduk (KTP). KTP dapat dimiliki oleh seseorang yang telah berusia 17(tujuh belas) tahun. Masyarakat secara umum menganggap usia 17 tahun sudah dianggap dewasa. Sesungguhnya secara hukum usia dewasa tersebut tidak ada keseragaman menurut hukum yang berlaku di Indonesia.

Seseorang dalam kehidupannya akan tumbuh dan berkembang. Mulai dari bayi sampai dewasa. Perubahan tersebut bertahap, di mulai dari seseorang itu masih bayi, lalu masuk usia anak dibawah umur, lanjut menjadi remaja, sesudah lewat masa remaja menuju dewasa atau tua. Tahap tersebut dilewati seseorang dengan perubahan secara fisik dan psikis. Istilah dewasa menggambarkan segala organisme yang telah matang, lazimnya merujuk pada manusia, orang yang bukan lagi anakanak dan telah menjadi pria dan wanita dewasa(Yusuf,2000:14).

Secara psikologis, Singgih Gunarso mengelompokkan tingkatan usia dikaitkan dengan kondisi kejiwaan seseorang sebagai berikut :

(1) Anak adalah seseorang yang berumur di bawah 12 tahun ; 
(2) Remaja dini adalah seseorang yang berumur antara 12-15 tahun;

(3) Remaja penuh adalah seseorang yang berumur antara 15-17 tahun;

(4) Dewasa muda adalah seseorang yang berumur antara 17-21 tahun;

(5) Dewasa penuh adalah seseorang yang berumur di atas 21 tahun.

Menurut MM Djojodigoeno dalam Sainul (2019:261-262) bahwa batas antara telah dewasa dan belum dewasa hanya dapat dilihat dari kecakapan melakukan perbuatan hukum. Mereka yang belum cakap melakukan hukum adalah orang yang belum mampu memperhitungkan dan memelihara kepentingannya sendiri. Orang yang cakap hukum berarti orang yang mampu memperhitungkan dan memelihara kepentingannya sendiri .

Menurut Pasal 2 Kitab UndangUndang Hukum Perdata(KUHPer) bahwa manusia menjadi pendukung hak dan kewajiban dalam hukum sejak lahir sampai meninggal, tetapi tidak semua orang sebagai pendukung hukum (recht) adalah cakap (bekwaam) untuk melaksanakan sendiri hak dan kewajibannya. Kecakapan (atau yang lebih sering disebut dewasa) merupakan unsur melakukan suatu perbuatan hukum. Dalam hal ini, kecakapan sering dikaitkan langsung dengan batas usia seseorang. Sebagaimana ditegaskan pula oleh Lestari (2008) bahwa kecakapan bertindak seseorang sebagai subyek hukum dalam tindakan hukumnya dikaitkan dengan faktor kedewasaan, yang didasarkan antara lain atas dasar umur Menurut Arifianto dkk (2014) bahwa kecakapan sering kali disebut sebagai faktor utama ketika ingin melakukan suatu perbuatan di masyarakat pada umumnya. Berbagai macam hukum dan perundang-undangan yang mengatur tentang hal kecakapan hukum melakukan perbuatan hukum baik tertulis maupun tidak tertulis.

Sebagian besar munculnya hakhak (subyektif) dan kewajibankewajiban hukum, dikaitkan dengan atau terjadi melalui tindakan hukum. Sedangkan yang dimaksud dengan tindakan hukum, adalah tindakantindakan yang menimbulkan akibat hukum dan akibat hukum itu dikehendaki atau dapat dianggap dikehendaki.

Sebenarnya tidak ada ketentuan dalam suatu peraturan perundangundangan yang khusus mengatur tentang 
kecakapan bertindak dan kedewasaan seseorang, sebagaimana dinyatakan dalam ketentuan Pasal 330 KUHPer. Ketentuan tentang batasan usia dewasa seseorang, tersebar dalam berbagai peraturan perundang-undangan di Indonesia (Kania,2020).

Mahasiswa yang rata-rata berusia 19 (sembilan belas) tahun dapat dianggap cakap hukum maka dapat melakukan perbuatan hukum. Berdasarkan hasil wawancara terhadap mahasiswa semester I(satu) pada program studi Pancasila dan Kewarganegaraan (PPKn) tahun ajaran 2021-2022 di Universitas Pasundan, menunjukkan bahwa salah satu contoh mereka telah melakukan perbuatan hukum adalah melaksanakan hak pilihnya dalam Pemilihan Umum (PEMILU) atau Pemilihan Kepala Daerah (PILKADA). Bahkan adapula mahasiswa yang sedang kuliah ini melaksanakan perkawinan. Melaksanakan perkawinan antara lakilaki dan perempuan itu pun termasuk perbuatan hukum.

Sayangnya sosialisasi tentang usia dewasa menurut hukum di Indonesia ini masih minim dan bukan menjadi bagian yang penting dalam materi Pendidikan Kewarganegaraan di perguruan tinggi bahkan di persekolahan. Bukti masyarakat masih awam tentang pengetahuan usia dewasa menurut hukum ini dapat kita lihat dalam kehidupan kita sehari-hari. Contohnya anak-anak Sekolah Dasar (SD) atau Sekolah Menengah Pertama (SMP) yang masih di bawah umur mengendarai sepeda motor dengan bebas di jalan raya. Meski mereka sudah dapat mengendarai sepeda motor dengan baik, namun secara hukum mereka belum berhak mendapatkan Surat Izin Mengemudi (SIM). Salah satu syarat memiliki SIM adalah memenuhi usia tertentu. Bila orang tuanya tahu dan faham akan pengetahuan usia dewasa menurut hukum, maka orang tua tersebut pasti akan melarang anaknya mengendarai sepeda motor. Selain masih di bawah umur, anak tersebut belum bisa bertanggung jawab atas perbuatannya mengendarai motor. Bila terjadi kecelakaan atau menabrak pengendara motor yang lain maka yang dimintai pertanggung jawaban adalah orang tuanya. Dengan demikian sangat jelas pengetahuan usia dewasa menurut hukum ini sangat penting difahami oleh seluruh warga negara Indonesia. Tidak terbatas pada mahasiswa-mahasiswa di perguruan tinggi. Adapun peluang 
sosialisasi tentang pengetahuan usia dewasa menurut hukum ini dapat dilakukan oleh calon-calon guru Pendidikan Pancasila dan Kewarganegaraan (PPKn) pada Fakultas Keguruan dan Ilmu Pendidikan (FKIP) di Universitas Pasundan. Maksudnya agar pengetahuan tersebut dapat dilakukan lebih awal di tingkat persekolahan.

\section{METODE PENELITIAN}

Metode penelitian yang digunakan dalam penelitian ini adalah metode studi kasus karena objek yang diangkat sebagai kasus adalah yang bersifat kontemporer, yakni yang sedang berlangsung atau telah berlangsung(Yin,2003).

Metode penelitian ini digunakan untuk dapat mengungkapkan bagaimana pemahaman mahasiswa PPKn semester 1 (satu) tahun ajaran 2021-2022 di Universitas Pasundan terhadap pengetahuan usia dewasa menurut hukum yang berlaku di Indonesia.

Langkah-langkah dalam penelitian dengan pendekatan studi kasus (Arifianto,2016:39-40) adalah sebagai berikut : 1)menentukan dan membatasi kasus-kasus yang akan dijadikan objek penelitian; 2)memilih fenomena,tema atau isu penelitian yang akan dijadikan studi kasus; 3) memilih bentuk-bentuk karakteristik data yang akan dicari dan dikumpulkan; 4)melakukan triangulasi untuk uji validitas data; 5)menentukan interpretasi-intrepetasi alternatif untuk diteliti kembali; dan 6)membangun dan mengidentifikasi hal-hal penting dari hasil-hasil penelitian terhadap "kasus" yang ditelitinya.

Teknik pengumpulan data yang digunakan dalam penelitian studi kasus ini adalah metode studi dokumentasi, observasi dan wawancara. Sumber data penelitian diperoleh dari literaturliteratur yang relevan seperti: buku, makalah atau artikel ilmiah, dan sebagainya. Observasi dilakukan untuk mengamati bagaimana sikap dan perilaku mahasiswa yang termasuk dalam kategori usia dewasa menurut hukum. Adapun wawancara dilakukan untuk menggali lebih dalam bagaimana pemahaman mereka atas pengetahuan usia dewasa menurut hukum yang berlaku di Indonesia terhadap hak dan kewajiban warga negara pada mahasiswa PPKn semester I(satu) tahun ajaran 2021-2022.

\section{PEMBAHASAN}

Hasil studi kepustakaan dan dokumentasi tentang usia dewasa 
menurut hukum yang berlaku di Indonesia menunjukkan bahwa tidak ada keseragaman penentuan usia dewasa ini. Dalam konsep hukum perdata menurut KUHPer adalah syarat bagi seseorang untuk dapat melakukan tindakan atau perbuatan hukum. Syarat yang dimaksud adalah cakap hukum. Secara ekplisit didalam KUHPer tidak disebutkan definisi kecakapan. Cakap (bekwaam) terkait kepada keadaan seseorang berdasarkan unsur fisiologis dan psikologis umur, melekat pada mereka yang telah tidak lagi (minderjarig/belum dewasa), yaitu setelah dianggap memasuki fase kedewasaan akhir atau disebut adulthood. Hal ini terkait dengan kapasitas mental dan akal sehat seseorang untuk mengetahui akibatakibat dari perbuatannya. Berdasarkan pada KUHPer, batasan umur dewasa seseorang diatur dalam Pasal 330 yang menentukan bahwa :

"Batasan dewasa adalah mereka yang belum mencapai umur genap 21 (dua puluh satu) tahun, dan tidak lebih dahulu telah menikah".

Di bawah ini perbedaan batasan usia dewasa menurut beberapa ketentuan hukum yang berlaku di Indonesia :

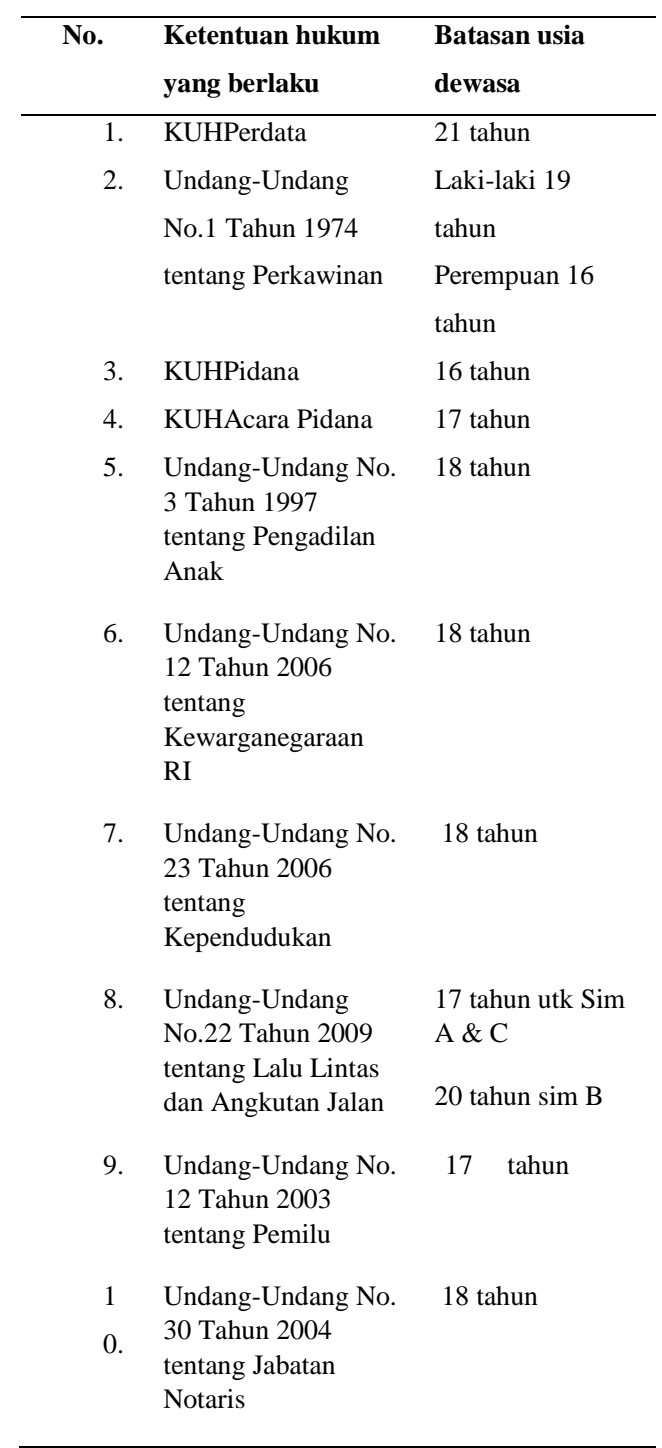

Sumber: (Bachri \& Kania, 2019, dialih bahasa Indonesia oleh penulis)

Pengetahuan hukum (Soekanto,1985) adalah pengetahuan seseorang mengenai beberapa perilaku yang diatur didalam hukum tertulis. Seseorang mengetahui bahwa perilakuperilaku tertentu itu telah diatur oleh hukum. Baik itu hukum tertulis maupun hukum yang tidak tertulis. Perilaku tersebut menyangkut perilaku yang 
dilarang oleh hukum maupun perilaku yang diperbolehkan oleh hukum.

Pengetahuan hukum yang dimaksud adalah pengetahuan seseorang tentang usia dewasa menurut hukum yang berlaku di Indonesia.

Pemahaman hukum (Soekanto, 1985) adalah sejumlah informasi yang dimiliki seseorang mengenai isi dari aturan hukum (tertulis), yakni mengenai isi, tujuan dan manfaat dari peraturan tersebut. ini memiliki arti bahwa seseorang dapat dikatakan memiliki pemahaman hukum jika mengetahui aturan-aturan hukum tersebut terutama dari segi isinya. Ini berarti orang tersebut sadar bahwa terdapat aturan yang mengatur perilaku tertentu, akan tetapi dia tidak mengetahui isi hukum tersebut atau hanya mengetahui sedikit tentang hukum tersebut. Sebagaimana hasil penelitian menunjukkan bahwa para mahasiswa semester I, merasa cukup tahu saja tentang usia dewasa menurut hukum. Untuk sampai ke pemahaman dari pengetahuan usia dewasa menurut hukum yang berlaku di Indonesia, menurut pendapat mereka, saat ini informasi apapun mudah didapat melalui internet. Bagi mereka informasi tentang usia dewasa menurut hukum itu akan di cari manakala benar-benar membutuhkannya.

Di dalam hukum, seseorang dapat dikatakan cakap bertindak adalah apabila seseorang tersebut telah dewasa. Menurut Pasal 2 KUHPer, manusia menjadi pendukung hak dan kewajiban dalam hukum sejak lahir sampai meninggal, tetapi tidak semua orang sebagai pendukung hukum (recht) adalah cakap (bekwaam) untuk melaksanakan sendiri hak dan kewajibannya. Kecakapan (atau yang lebih sering disebut dewasa) merupakan unsur melakukan suatu perbuatan hukum. Dalam hal ini, kecakapan sering dikaitkan langsung dengan batas usia seseorang.

Ketidakseragaman batas usia dewasa dalam ketentuan hukum yang berlaku di Indonesia bukan berarti tidak menjamin kepastian hukum. Tujuan negara memberlakukan suatu ketentuan itu pada dasarnya untuk melindungi kepentingan hukum seluruh warga negara Indonesia. Maka batasan usia dewasa menurut hukum ini berlaku disesuaikan dengan kepentingan masingmasing warga negara itu sendiri.

Hasil wawancara dari penelitian ini menunjukkan bahwa hampir seluruhnya mahasiswa semester 1 menjawab bahwa 
usia 17 (tujuh belas) tahun adalah usia dewasa menurut hukum. Padahal batas usia dewasa ini beragam. Mereka menganggap bahwa dengan memiliki KTP sudah dianggap dewasa. Adapun hak yang mereka dapatkan setelah berusia 17 (tujuh belas) tahun adalah dapat memiliki Surat Izin Mengemudi (SIM) dan turut serta memilih dalam PEMILU atau PILKADA. Adapun mahasiswa yang mengetahui usia dewasa menurut hukum adalah 21(duapuluh satu) tahun. Menurutnya informasi ini didapatkan dari internet . Selanjutnya pemahaman mahasiswa tentang usia dewasa menurut hukum terhadap hak dan kewajiban sebagai warga negara, hanya sebagian mahasiswa yang faham. Mereka masih belum dapat membedakan secara jelas apa saja hak dan kewajiban warga negara setelah mereka memasuki batas usia dewasa menurut hukum.

Menurut Hans Kelsen, hak adalah kepentingan yang dilindungi oleh hukum. Sehingga hak itu sah karena dilindungi oleh sistem hukum. Pemegang hak melaksanakan kehendak menurut cara tertentu dan kehendaknya itu diarahkan untuk memuaskan. (Mertokusumo , 2010 , Hlm. 60). Contoh Hak Warga Negara Indonesia : Setiap warga negara berhak mendapatkan perlindungan hukum.Salah satu contoh seseorang yang sudah dewasa dan cakap hukum dapat melakukan tindakan hukum tanpa perlu persetujuan dari orangtuanya. Namun hal ini dilihat kembali tindakan hukum apa yang dia akan lakukan. Karena dalam hal seseorang itu cakap hukum untuk melakukan tindakan tertentu, belum tentu ia wenang hukum. Contoh seorang calon mempelai wanita berusia 21 (duapuluh satu) tahun, beragama Islam. Meski sudah berusia dewasa dalam hal melakukan perkawinan sesuai ketentuan hukum Islam, maka yang bertindak sebagai wali nikah adalah ayah kandungnya. Maka yang memiliki kewenangan hukum menjadi wali nikahnya adalah ayah kandungnya. Jadi belum tentu yang cakap hukum itu memiliki kewenangan hukum.

\section{KESIMPULAN}

Pengetahuan tentang usia dewasa menurut hukum yang berlaku di Indonesia menjadi sangat penting bagi para mahasiswa di perguruan tinggi. Usia para mahasiswa baru semester 1(satu) rata-rata berusia antara 18(delapan belas) dan 19 (sembilan belas) tahun menunjukkan bahwa 
mereka telah memenuhi syarat cakap hukum. Dalam arti mereka dapat bertindak sendiri tanpa persetujuan orang tuanya. Namun ini bukan berarti seseorang yang sudah berusia dewasa menurut hukum dapat melakukan apa saja sekehendaknya. Walaupun tidak ada keseragaman usia dewasa menurut hukum yang berlaku di Indonesia, bukan berarti tidak menjamin kepastian hukumnya. Justeru disini negara berusaha melindungi kepentingan warga negara sesuai dengan kebutuhannya masing-masing. Sosialisasi pengetahuan usia dewasa menurut hukum menjadi kebutuhan dan sangat penting diketahui serta difahami oleh para mahasiswa di perguruan tinggi. Agar para mahasiswa dalam melakukan tindakan hukum tertentu dapat memahami hak dan kewajibannya sebagai pribadi dan warga negara. Khususnya bagai mahasiswa program studi PPKn sebagai calon guru Pendidikan Kewarganegaraan(PKn). Salah satu tujuan PKn adalah untuk menjadikan warga negara yang baik. Maka dengan turut serta mensosialisasikan pengetahuan usia dewasa menurut hukum melalui mata pelajaran Pendidikan Pancasila dan Kewarganegaraan akan memberikan pengetahuan lebih dini tentang usia dewasa menurut hukum bagi para peserta didik . Ini dimaksudkan agar tidak terjadi lagi anak-anak di bawah umur melakukan sesuatu yang tidak sesuai dengan umur dan kemampuan mereka untuk bertanggung jawab atas setiap tindakan yang mereka lakukan.

\section{DAFTAR PUSTAKA}

\section{Buku :}

Arifianto.S.(2016). Implementasi Metode Penelitian "Studi Kasus" Dengan Pendekatan Kualitatif. Cet.1, Yogyakarta: Aswaja Pressindo.

Mertokusumo, Sudikno.(2010).

Mengenal Hukum Suatu

Pengantar(edisi revisi), Yogyakarta: Cahaya Atma Pusaka

Subekti \& Tjitrosudibjo.(1980). Kitab Undang-Undang Hukum Perdata (Burgerlijk Wet Boek). Jakarta. Pradnya Paramita.

Soekanto, Soerjono.(1985). Perspektif Teoritis Studi Hukum Dalam Masyarakat. Jakarta: Rajawali Pers.

Yin, Robert K. (2012), Studi Kasus Desain \& Metode(Edisi Revisi), Jakarta:Rajawali Press.

Yusuf, Syamsu. (2000) . Psikologi Perkembangan Anak \& Remaja, Cetakan ke-1, Yogyakarta :Rosda

Tesis :

Lestari, Ningrum Puji,(2008). Kecakapan Bertindak Dalam Melakukan Perbuatan Hukum Setelah Berlakunya UndangUndang Nomor 30 Tahun 2004 
Tentang Jabatan Notaris, Tesis, SPs Universitas Dipenegoro, Tidak diterbitkan.

\section{Jurnal :}

Arifianto Dedik, Dominikus Rato \& Sriono Edy.(2014). Kecakapan Seseorang Dalam Melakukan Perbuatan Hukum Menurut Hukum Adat Suku Tengger diakses dari

http://repository.unej.ac.id/bitstrea $\mathrm{m} /$ handle/123456789/58918/Dedik $\%$ 20Arifianto\%20.pdf? sequence $=1$ \&isAllowed=y tanggal 02-11-2019

Bachri, Asep Syamsul \& Kania, Delila.

(2019). The Importance of Adult Concept Materials in the Learning of Civic Education at University, OCEANIDE: Vol 12, No 1 diakses dari https://oceanidenetne.net/index.php/ o tanggal 07-02-2022

Kania, Delila.(2020). Nilai Kesundaan Cageur (sehat akal), Bageur (baik) dan Bener (benar) sebagai Kearifan Lokal Dalam Perspektif Konsep Hukum Perdata di Indonesia. Vol 3 ,No 2, Civic Edu: Jurnal Pendidikan Kewarganegaraan diakses dari https://www.journal.unpas.ac.id/index .php/civicedu/article/view/4626 tanggal 07-02-2022

Sainul, Ahmad.(2019). Konsep Kedewasaan Subjek Hukum, Jurnal El-Qanuny, Vol 5,No.2, Edisi Juli Desember

\section{Seminar :}

Gunarso Singgih, Perubahan Sosial Dalan Masyarakat, Makalah seminar Keluarga dan Budaya Remaja di Perkotaan, Jakarta : Pusat antara Universitas Ilmu-Ilmu Sosial, Universitas Indonesia, 1989,hlm.2 